\title{
Sustainability and cleaner production principles in micro furniture companies: two Brazilian cases
}

\author{
Catarina Costa de Souza ${ }^{a}$ Luana Lott Alves ${ }^{b}$, Eduardo Romeiro Filhoc \\ "Escola de Design, Universidade do Estado de Minas Gerais - UEMG \\ 'Mestrado Profissional em Inovaç̃ão Tecnológica e Propriedade Intelectual, Universidade do Estado de Minas Gerais - UFMG \\ e-mails: catarinacostadesouza@gmail.com; luanalott@gmail.com; romeiro@dep.ufmg.br
}

\begin{abstract}
This paper presents the results of an environmental, technological and economic research, focusing on the management and operation of two small furniture companies in Brazil, aiming to analyze the level of raw material loss and waste generation during the production process. The companies studied are located in Manaus and Belo Horizonte, regions of different social, economic and technological context. Concepts such as Cleaner Production, Eco-efficiency, Eco-design and Product Development were addressed, aiming at an improvement proposal adequate to the real needs and limitations of each company. For that, the organizational characteristics were surveyed and the production processes adopted were described and evaluated. The study conclusions indicate that companies have very distinct features, which prevent the application of traditional systematic management tools. Moreover, research demonstrate that Product Development Process is not a defined process in the observed companies and the proximity of a raw material source (in this case, the Amazon forest) does not contribute decisively to the needs and problems related to the production processes.
\end{abstract}

Keywords: cleaner production, micro e small companies, furniture industry, Brazilian Amazon.

\section{Introduction}

The furniture industry in Brazil is among the most important segments of the manufacturing industry in the country, due to the importance of its production value and the expressive generation of jobs in industry, according to a study by Abimóvel (ASSOCIAÇÃO..., 2006). The furniture industry in Brazil is characterized as a traditional sector focused basically on the domestic market, formed predominantly by micro and small companies, whose development process, until reaching the production of serial goods, is closely linked to the growth of old carpentry that worked on the small-scale on-demand production (CENACHI; ROMEIRO FILHO, 2004). The production of wood furniture is based on the activity of carpentry, which is the denomination for the preparation and carving of wood for the production of useful and decorative objects (INSTITUTO..., 2014).

The sector is characterized by the functional and managerial disorganization of the productive sector, resulting in low process efficiency and high waste rate. Research carried in Manaus conclude "[...] the waste of wood is considered a bottleneck in the segment, timber reaching $70 \%$ the amount of waste underutilized for lack of knowledge about its use [...]" (FAPEAM NOTÍCIAS, 2012). The main losses in this activity are linked to the waste of both, resources and human labor, which leads the sector to low productivity (SOUZA et al., 2015). As the production process is discontinuous, it is possible that obsolete machines coexist with modern ones on the same production line. It is worth mentioning that most companies in the sector continue to operate with outdated machinery and production systems (ALMEIDA et al., 2014). On the other hand, it is an opportunity to improvement by product development using sustainable principles, as demonstrated by Barata et al. (2016) and Chaves (2008).

For the development of this work, the mapping and evaluation of the production processes of two small furniture companies located in two distinct regions of the country were carried out: one in Manaus, in the Amazon region in the north of the country and another in Belo Horizonte, one of the largest and most developed cities in the country, located in southeastern Brazil. The initial objective of the research was to point out the phases where the losses of raw material occur, focusing on solid wood and MDF, from the raw material input to the end given to the residues generated in the manufacturing and propose an understanding about the optimization of these processes in local micro and small enterprises. It was also sought to 
study the technical and organizational characteristics of these small producers so that, respecting this reality, and in view of the general survey of the production process, a proposal for improvement in the productive process of the companies, using the principles of the Cleaner Production methodology, so that associated to Product Development Process can add value and benefits to the furniture sector, especially in small companies. Finally, we sought to observe the influence of the local reality on the business and on the results obtained by the companies, especially considering the situation of the company located in Manaus and its proximity to the Amazon forest. The methodology used was the case study (YIN, 2013): data collection and analysis tools included direct observation, visual recording of the production process, interviews with employees and mapping of the production process.

As a result, it was verified that the furniture sector in Manaus has typical characteristics of a small company constituted without planning: the carpenters have knowledge and experience with the work that is done but lack the knowledge in company management principles, which can hinder the continuity and success of the business. As a positive aspect, it was observed that, in addition to technical capacity, these employees seek to work with a demand for services that are able to complete and meet deadlines.

On the other hand, the furniture sector in Belo Horizonte presents characteristics of better strategic planning, works with more practical raw materials, but does not develop environmental management, to discard the residual material, or to prevent leftovers and residues; although carpenters also have a good knowledge of the techniques, there is no concern with costs or with the material left over from the production process. It was observed that these factories have quite peculiar characteristics, which hinder the systematized application of traditional management tools. On the other hand, the study indicates that the adequacy of these tools to the reality of small and micro companies (SMCs) can bring relevant benefits to these companies.

This article is organized in six sections, as described below. The second section deals with a literature review, where the main concepts for understanding the theme are described. The third section presents the methodology that was used to develop this work. In the fourth section, the case study was carried out in two furniture companies, one in the city of Manaus, in the state of Amazonas, and the other in the city of Belo Horizonte, in the state of Minas Gerais. In the fifth section we present the results and discussions about the case studies with the comparative about the operation of the two companies. Finally, the sixth section presents the conclusions of the study.

\section{Literature review}

In the last years of the twentieth century, it was fundamental for business management to understand the importance of adopting a more efficient production in terms of prevention of contamination and environmental pollution. Cleaner Production is a concept that has come to be discussed and disseminated in the business world as a way to make the production activity simultaneously less harmful to the environment and more efficient. This concept can be understood as an environmental strategy and be adopted as pollution prevention for the development of business processes, products, and services (PROGRAMA..., 1992). It is a process that seeks continuous improvements, with the objective of reducing the environmental damages caused by the productive activity.

The procedures adopted by this strategy are focused on production processes, with a concern for the consumption of raw materials and energy, eliminating or reducing the toxicity of waste emissions; in order to reduce the negative impact on the life cycle through the development of an adequate design for products and services, with the insertion of environmental concern in their supply (DIAS, 2011).

It also proposes the provision of information on the environmental risks that products or processes may entail and in the case of application of Cleaner Production in productive processes, it values the more efficient use of raw materials, inputs and energy, as well as the search for reduction of the use of hazardous materials and also provides for the minimization of the generation of solid waste, effluents and emissions in a way that causes less damage to the environment (KIPERSTOK et al., 2002).

In order for companies to perceive and apply the concepts of environmental sustainability in their management, it is necessary to reflect on how sustainable, economic and social development are incorporated by organizations. In this perspective, environmental management and social responsibility become important administration tools for training and creating conditions of competitiveness for companies in any economic segment (TACHIZAWA, 2002).

The concept of sustainable development is very broad; in addition to believing in continuous economic growth by making use of natural resources more consciously and less polluting, there is also a need to reflect on how to obtain social and political projects as a means to combat poverty and promote the life quality of people, so that it can meet the basic needs of the population and provide subsidies for the harmonious development of society and the use of natural resources (DIAS, 2011). It is important to encourage the small producer and entrepreneur, with opportunities to improve their activities, as a way to contribute to social and economic development. In order to build sustainable development in a comprehensive way, other dimensions 
than ecological, such as social, cultural, environmental, territorial, economic and political, must be considered as a way of ensuring that sustainable development takes place for in addition to economic growth and the mere multiplication of material wealth, with the reduction of social inequality and the extermination of poverty, in order to fulfill the requirement of being a necessitous condition for the improvement of life for all (SACHS, 2008).

Small and micro businesses tend to use these measures as a guide to their actions. This is important for this study since they stand out as potential within the Brazilian economy. These companies have assumed a level of importance in the Brazilian market, as they are responsible for generating income and jobs, as well as absorbing less skilled labor and allowing the spraying of businesses throughout Brazil, allowing income generation and capital circulation (SERVIÇO..., 2016). It is important for SMCs to become competitive and, whenever possible, to enter into global international markets. Therefore, it is believed that competitive advantage and international insertion can be achieved through Eco-efficiency, without causing large financial expenditures (ALVES et al., 2009).

\section{Method}

A series of technical visits were conducted to the companies, including work observation, non-stealth document analysis and interview with the owners. The interview were based on an open and semi-structured script to collect information about the company, its products and production processes. The research was carried out at a local workshop to identify, detect and map the current production process within woodworking in Manaus and Belo Horizonte. In order to visualize the degree of difficulties and real needs of the joinery. In this stage, an observation was also made of the work routines of the workers, which allowed the registration of the questions related to the object of study. Subsequently a script was developed during the second part of the field study to analyze the production process in the furniture company in Manaus. The questions generated in this topic served as a guide for the diagnosis of production and possible implementation of Cleaner Production opportunities. For this purpose, the work of Massote (2010) and the Cleaner Production methodology (KIPERSTOK et al., 2002) were used.

\section{Case studies}

\subsection{Case study one: furniture company in Manaus}

The first company studied was founded with the purpose of manufacturing, assembling, remodeling and finishing the furniture products for commercial and personal use. Regarding the development and design of the products, the company reported that most of the projects are forwarded by an architect. In the projects followed during the research, there was no technical drawing, the architect only made a draft (Figure 1) of the project and the measures were discussed and decided informally with the carpenters. This makes it difficult (for example) to plan cuts, which increases the waste of wood during the production process.

The company works predominantly with solid wood and MDF (medium-density fiberboard) and performs the whole process of wood treatment, cutting, pigmentation and assembly of the products. For the purpose of this research, it was observed the production of four furniture in the company, two employing solid wood and two using primarily MDF. The place where the company operates is rented and consists of a shed of $7 \mathrm{mx} 20 \mathrm{~m}$ (Figure 2), with an internal bathroom, and an external area of $7 \mathrm{mx} 5 \mathrm{~m}$ which serves as both material storage area and painting area. When the owners took over, there was already a part of the machinery for the work.

The work area has a lot of leftover material from previous jobs (Figure 3), accommodated throughout the

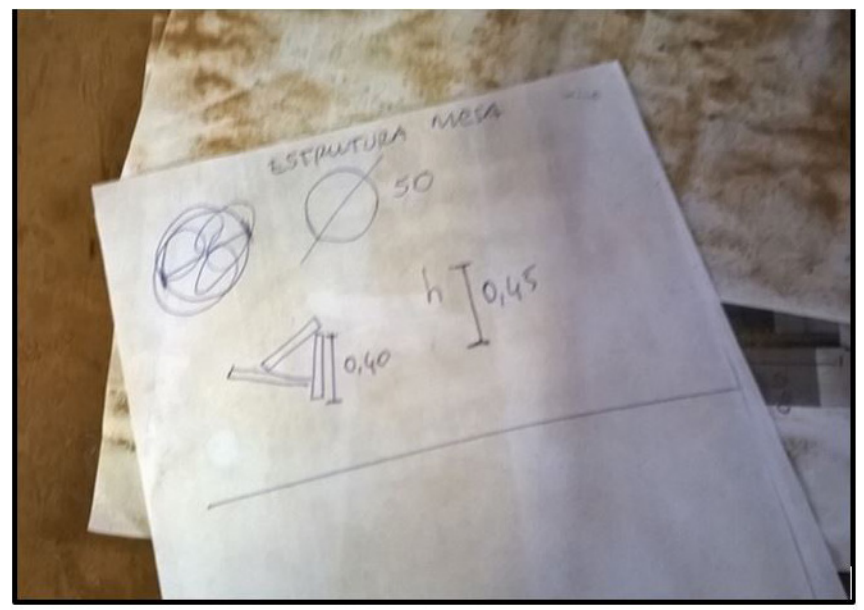

Figure 1. Example of sketching used during the furniture production process.

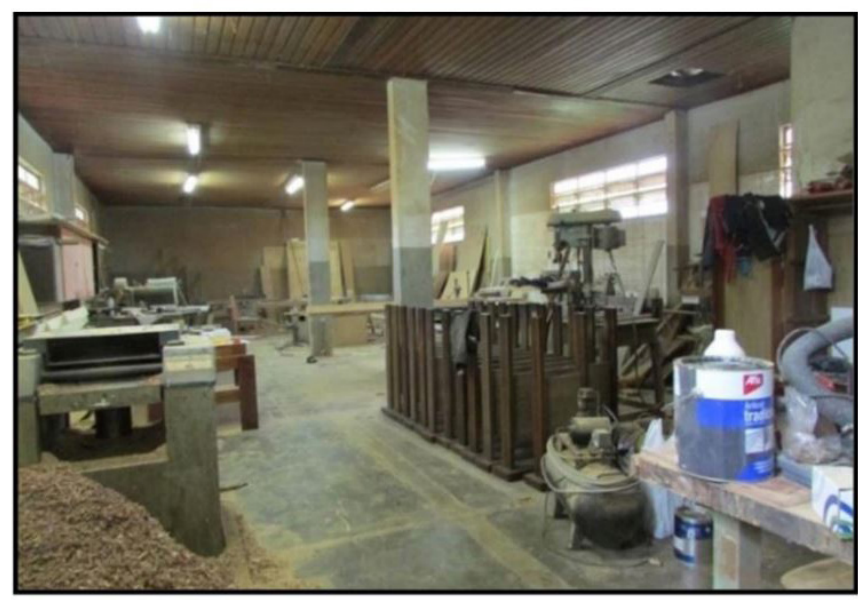

Figure 2. Internal view of the Manaus company. 
workshop and stored without cataloging of size or type of wood. There is no reuse planning for the leftover wood. At the end of production, only the material that can be used later in other jobs is stacked.

The research allowed us to describe some factors that make it difficult to implement Cleaner Production in the company of Manaus and to understand the barriers that can be avoided or improved in the company so that this implementation can happen. Regarding the knowledge of the Cleaner Production methodology by the company, the partners demonstrated that they did not know the method and had no concern about using an environmental improvement process. However, they have not been opposed to a future use of it, since it is mainly interested in improving the image of the company in front of the public, besides the concern with the environment.

In relation to the organizational barrier, both partners that form the company are carpenters and simultaneously responsible for all production. The two have the knowledge of the carpentry activity, but one has training in woodwork at a technical school. As for the attitude barrier, the partners affirm that in the case of the small producer it is difficult to achieve a change in the way of producing with the limited resources they have, mainly in the acquisition of certified wood and in the final disposal of the waste, because for the realization of correct disposal it is necessary to pay a vehicle of the prefecture to collect the waste in the workshops of the municipality.

Regarding the economic barriers, the carpenters explained that the biggest difficulty for the small producer is that they do not have the financial resources to invest in new technologies and more recent machines or in employees to assist in the work, indicating these factors as limiters for the implantation of an environmental management system. Regarding the structural barriers in furniture, it was observed that the heavy machinery used in the production processes are outdated models and that they present the need for maintenance during the work. Although they are in operation and meet the needs of the tasks developed, they do not facilitate the work as in the case of more modern models, which avoid deterioration.

Finally, with regard to government barriers, there is no policy by the government or prefecture that provides personnel training and companies regarding the use and raw material disposal, or incentive to purchase more modern equipment for the small producer, although there is the prefecture surveillance in furniture industries to verify the operation of the same.

\subsection{Case study two: furniture company in Belo Horizonte}

The company has 32 years of existence and currently works with custom furniture. The owner, who is also a manager, inherited the company from his father. This company analyzed also works with furniture to order, from hiring professionals by the client or by the company's own project. When the project is carried out by professionals external to the company, details such as measures, materials, delivery times and details are discussed and determined by company. The project can also be done internally, when the company manager develops the design, both for presentation to the client and for the production process. In the product development, the manager counts on the help of an assistant in the preparation of the drawings and determination of the measures (Figure 4).

The raw material used is $95 \%$ made of MDF, and solid wood is used only for some structures, such as door frames. The operating place is owned by the company and consists of a shed of $24 \mathrm{mx} 20 \mathrm{~m}$ that has low ventilation (Figure 5). The factory works with dedicated equipment for the production using the MDF: two circular saw machines for cut and square cuts, a thickness planer machine, a bench with three vertical drills and a bench with milling router. According to the manager, other machines that were used in solid wood processes were sold because they were no longer useful as to the raw material in use.

The company also has a storage area for the leftovers (Figure 6), which facilitates the visualization and cataloging

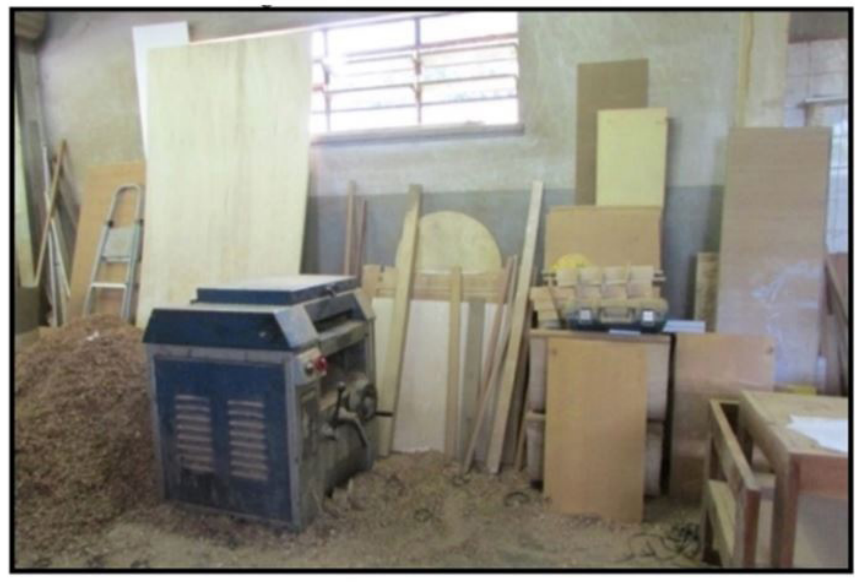

Figure 3. Material leftover from the company in Manaus.

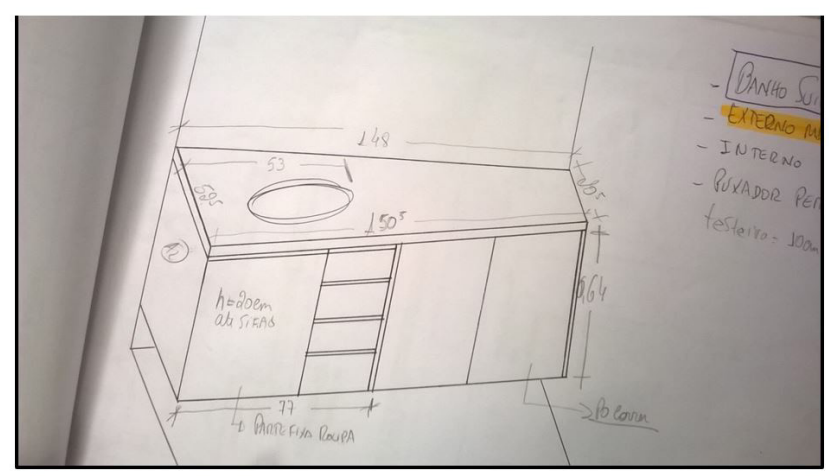

Figure 4. Project developed in the company. 
of the MDF. In these shelves are stored the newly purchased plates and the oversized leftovers that can be reused in other processes. This format, according to the manager, was one of the facilitating actions acquired with a consultancy carried out by SEBRAE.

On the knowledge of the Cleaner Production Methodology by the company, it was observed that the agents are not aware of the method, but understand that avoiding the waste can generate financial savings, which is beneficial for the company. The manager does not demonstrate to be contrary to the application of an environmental management in the productive process but explains that the implantation of improvements is more problematic in a moment of difficulty due to the decrease of orders.

As for the organizational barriers, the employees help to account for the MDF that they used in furniture production. They are satisfied with the way the project is presented and the communication with management to answer questions. But they say that the division of labor and the way furniture is produced can be improved by replacing the equipment

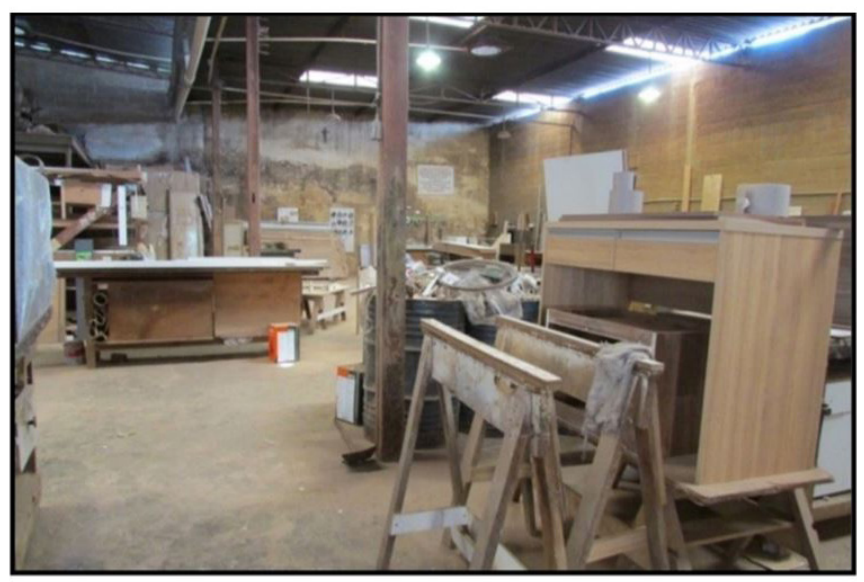

Figure 5. Internal view of the company in Belo Horizonte.

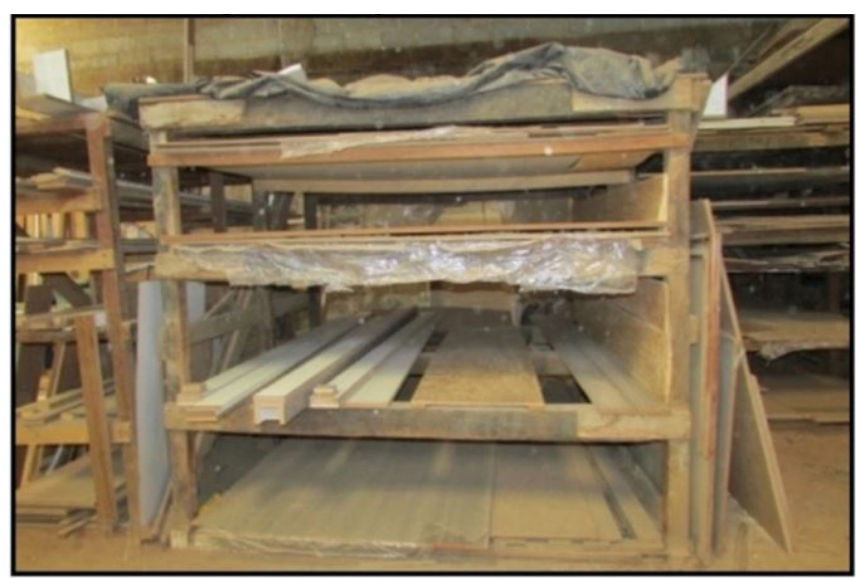

Figure 6. Internal view of the company in Belo Horizonte. in the workshop. With regard to the attitude barrier, the company manager was very accessible to the study and the possibilities of change.

Regarding the existing economic barriers, today the company faces economic problems with the lack of customers and, therefore, radical changes in the process are more difficult to be implemented. However, even in the period when production was higher, improvements with lower costs were not implemented. Regarding the structural barriers, the company works with minimum machinery for the processing of MDF. The use of more modern machines would help both in the production process and in the use of waste that is discarded.

\section{Result and discussion}

During the research done in the furniture factory in Manaus, it was verified that this one has characteristics of small company constituted without planning. The carpenters have knowledge and experience with the work developed but lack the knowledge in the company management, what can hinder the continuity and success of the business. As a positive aspect, it was observed that, in addition to technical capacity, these seek to work with a demand for services that they are able to complete and meet deadlines.

The furniture factory in Belo Horizonte presents better strategic planning and works with a more practical raw material. However, it does not develop environmental management for waste material disposal or leftovers and waste prevention. Although the carpenters have good knowledge for the activity execution, there is no concern with costs related to the material leftover from the production process. The comparative table below (Table 1) presents a characterization of the two companies operation, with the purpose of better visualization of the data collected:

In spite of the regional differences, the studied companies have a remarkable similarity among themselves, being characterized by acting in their businesses concentrating tasks as the capture of clients, contacts with professionals and development of the project, besides the process of manufacturing the mobile by a reduced number of people. This, with little or no financial capacity for expansion and new investments. Thus, the characteristic stages of the insertion of a Design Management into a formally structured company are difficult to companies of this size, considering, in addition to the financial question, problems such as lack of organization and documentation of processes.

The companies studied lack business planning to organize the work and propose strategic long-term goals. On the other hand, these have the advantage that in the small organization, access to management is facilitated, since the employees themselves act as managers. A possible design intervention for the environment can be well accepted, since in both companies the agents were interested in 
Table 1. Comparison of the two companies studied.

\begin{tabular}{|l|l|l|}
\hline \multicolumn{1}{|c|}{ Situation observed } & \multicolumn{1}{|c|}{ Manaus } & \multicolumn{1}{|c|}{ Belo Horizonte } \\
\hline Product Design. & External design to order (basically sketch). & $\begin{array}{l}\text { Design from hiring professionals by the client or by } \\
\text { the company's own. }\end{array}$ \\
\hline Disposition of internal space & $\begin{array}{l}\text { The furniture industry space is wide, but there are } \\
\text { machines that are not used in the production process. }\end{array}$ & $\begin{array}{l}\text { Each carpenter has his or her own workbench, the } \\
\text { existing machinery is leaner, only to work with } \\
\text { the MDF material, and there is adequate space for } \\
\text { stocking and storing the material. }\end{array}$ \\
\hline Use of polluting raw material & $\begin{array}{l}\text { The company works with solid wood and MDF. The first } \\
\text { has the possibility of being used in other cycles in the } \\
\text { environment. The MDF must conform to other forms of } \\
\text { disposal, which are not assimilated by the environment. }\end{array}$ & $\begin{array}{l}\text { The company works almost exclusively with the } \\
\text { MDF and this needs to be treated for disposal, they } \\
\text { are not assimilated into the environment, but the } \\
\text { waste is disposed of in ordinary landfills. }\end{array}$ \\
\hline $\begin{array}{l}\text { Possibility of waste being reused } \\
\text { in other sectors }\end{array}$ & $\begin{array}{l}\text { The company has no planning for waste material to } \\
\text { be reused in its own production, nor in other sectors } \\
\text { of other companies. }\end{array}$ & $\begin{array}{l}\text { The company has no planning for the waste generated } \\
\text { to be used by other industrial sectors but has the } \\
\text { practice of reusing leftovers in the production itself. }\end{array}$ \\
\hline
\end{tabular}

the changes, even though they did not know the Cleaner Production program.

\section{Conclusion}

This study demonstrated that the companies studied do not perform actions related to the issue of improving environmental standards or, when they act, do so in an incipient way. The research limits to recommending that the application of Cleaner Production principles in both companies should focus on the prevention of raw material waste, which was evident in the data collection. Actions related to the first level, specifically in the modification of the process, such as the acquisition of new machinery, application of simple tools like $5 \mathrm{~S}$, and actions in the structural scope, can be of great value for the positioning of the small company in the direction of environmental management.

Regarding the Product Development Process, the research did not identify a formal or structured process in both companies. It is not a surprise, considering the situation observed in Brazilian small companies in general. However, it was observed an interest of companies to the introduction of some "good practices" that could be included an adequate method to product improvement based on an application of principles of product design methodology. The problem in this case is similar to others small companies: the low investment capacity in financial terms and limited access to an adequate support from business support services. Regarding this aspect, the company located in Belo Horizonte presents some interesting results from this kind of intervention, but not related to product development process or cleaner production principles.

This research demonstrated an opportunity to develop a comprehensive approach on the Brazilian SMEs problems, including product development, production process and environmental sustainability. The common points of observed demands in different localities (Manaus and
Belo Horizonte) and (on the other hand) the singularity of Brazilian SMEs situation demonstrated that it is possible to systemic approach in terms of sustainability and cleaner production.

\section{Acknowledgements}

This research was sponsored by the Amazonas State Research Foundation - FAPEAM and Brazilian National Council for Scientific and Technological Development (CNPq), an agency linked to the Ministry of Science and Tecnologia (MCT) of Brazil. The authors would like $t$ thanks FAPEMIG - Foundation for Research Support of the State of Minas Gerais (FAPEMIG) by financial support to project TEC - APQ-01843-15 with the project: "Life Cycle Analysis of Products from Minas Gerais".

\section{References}

ALMEIDA, J. F. F. et al. Elaboração do PCP em uma indústria moveleira de pequeno porte. In: ENCONTRO NACIONAL DE ENGENHARIA DE PRODUÇÃO, 34., 2014, Curitiba. Anais... Rio de Janeiro: Associação Brasileira de Engenharia de Produção, 2014.

ALVES, J. L. S. et al. A viabilidade da ecoeficiência como fonte de inovação e ganho competitivo nas micro e pequenas empresas brasileiras. In: CONGRESSO NACIONAL DE EXCELÊNCIA EM GESTÃO, 5., 2009, São Domingos. Anais... Niterói: UFF, 2009.

ASSOCIAÇÃO BRASILEIRA DAS INDÚSTRIAS DO MOBILIÁRIO - ABIMÓVEL. Panorama do setor moveleiro no Brasil: informações gerais - dez. 2006. Available from: <http://www.sebraego.com.br/site/ arquivos/downloads/Panorama do Setor Moveleiro no Brasil_23758.pdf $>$. Access in: 15 June 2018.

BARATA, T. Q. F. et al. Furniture design using MDF boards applying concepts of sustainability. Product, v. 14, n. 1, p. $68-83,2016$. http://dx.doi.org/10.4322/pmd.2016.008. 
CENACHI, G. S.; ROMEIRO FILHO, E. Micro e pequenas empresas moveleiras - ontem, hoje e sempre? Um estudo feito no Vale do Jequitinhonha. In: ENCONTRO NACIONAL DE ENGENHARIA DE PRODUÇÃO ENEGEP, 24., 2004, Florianópolis. Anais... Porto Alegre: ABEPRO, 2004.

CHAVES, L. I. Design for sustainability: a methodological approach for the introduction of environmental requirements in the furniture sector. Product, v. 6, n. 2, p. 167-171, 2008.

DIAS, R. Gestão ambiental: responsabilidade social e sustentabilidade. 2. ed. São Paulo: Atlas, 2011.

FAPEAM NOTÍCIAS. Pesquisa analisa o potencial madeireiro do Amazonas. 2012. Available from: http:// www.fapeam.am.gov.br/pesquisa-analisa-o-potencialmadeireiro-do-amazonas. Access in: 8 May 2017.

INSTITUTO DE ESTUDOS E MARKETING INDUSTRIAL - IEMI. Relatório setorial da indústria de móveis no Brasil. 2014. Available from: <http://www.iemi.com.br/ press-release-iemi-lanca-relatorio-setorial-da-industria-demoveis-no-brasil/>. Access in: October 9th 2018.

KIPERSTOK, A. et al. Prevenção da poluição. Brasília: SENAI/D, 2002.

MASSOTE, C. H. R. Implementação da metodologia da produção mais limpa em uma indústria moveleira da região metropolitana de Belo Horizonte. 2010. 257 f. Dissertação (Mestrado em Engenharia Ambiental)Programa de Pós-graduação Engenharia Ambiental, Universidade Federal de Ouro Preto, Ouro Preto, 2010.
PROGRAMA DAS NAÇÕES UNIDAS PARA O MEIO AMBIENTE-UNEP. Design for sustainability. Nairobi: UNEP, 1992. Available from: <http://www.unep.org/resourceefficiency/ Business/SustainableProducts/DesignforSustainability/ tabid/78845/Default.aspx $>$. Access in: 15 Oct 2016.

SACHS, I. Desenvolvimento: includente, sustentável, sustentado. Rio de Janeiro: Garamond, 2008.

SERVIÇO BRASILEIRO DE APOIO ÀS MICRO E PEQUENAS EMPRESAS - SEBRAE. Faturamento mensal das MPE: micro e pequenas empresas no Brasil. 2016. Available from: $<$ https://www.sebrae.com. br/sites/PortalSebrae/estudos_pesquisas/faturamentomensal-das-mpe-no-brasildetalhe48,5c38ed2801794 510VgnVCM1000004c00210aRCRD>. Access in: 18 Dec 2016.

SOUZA, M. L. P. et al. Profissionalização na indústria moveleira: um estudo de caso em empresa familiar mineira. In: ENCONTRO NACIONAL DE ENGENHARIA DE PRODUÇÃO, 35., 2015, Fortaleza. Anais... Rio de Janeiro: Associação Brasileira de Engenharia de Produção, 2015.

TACHIZAWA, T. Gestão ambiental e responsabilidade social corporativa: estratégias de negócios focadas na realidade brasileira. São Paulo: Atlas, 2002.

YIN, R. K. Case study research: design and methods (applied social research methods). 5th ed. London: SAGE Publications, Inc., 2013. 